\title{
Die belang van die verrekening van metateoretiese vertrekpunte vir prediking en wetenskaplike navorsing in Homiletiek
}

\begin{abstract}
Authors:
Fritz W. de Wet ${ }^{1}$

Hennie J.C. Pieterse ${ }^{2}$

Affiliations:

${ }^{1}$ School of Ecclesiastical

Studies, North-West

University, Potchefstroom

Campus, South Africa

${ }^{2}$ Department of Philosophy,

Practical Theology and

Systimatic Theology,

University of South Africa,

South Africa

Correspondence to:

Fritz de Wet

Email:

fritz.dewet@nwu.ac.za

Postal address:

PO Box 19120, Noordbrug

2522, South Africa

Dates:

Received: 22 June 2011

Accepted: 13 Sept. 2011

Published: 10 Dec. 2012

How to cite this article: De Wet, F.W. \& Pieterse, H.J.C., 2012, 'Die belang van die verrekening van metateoretiese vertrekpunte vir prediking en wetenskaplike navorsing in Homiletiek', In die Skriflig/ In Luce Verbi 46(2), Art \#106, 9 pages. http://dx.doi. org/10.4102/ids.v46i2.106
\end{abstract}

(C) 2012. The Authors Licensee: AOSIS OpenJournals. This work is licensed under the Creative Commons Attribution License.
Hierdie artikel vorm deel van die tweede fase van die navorsingsprojek Metateoretiese vertrekpunte in Praktiese Teologie. Die probleem wat ondersoek word, het te doen met die onvermoë om rekening te hou met verskuiwings in die onderliggende metateoretiese voorveronderstellings in die praksis van prediking, sowel as in die aanpak van wetenskaplike navorsing in die vakgebied van Homiletiek. Ons fokus op die invloed van metateoretiese voorveronderstellings in die kommunikatiewe dimensie van werklikheidsbeskouing, hermeneutiese beskouinge rakende die kommunikatiewe veld wat werksaam is tydens die homiletiese proses, asook op die verrekening van wetenskapsteoretiese beskouinge met die oog op 'n verantwoordelike uitvoer van die wetenskaplike taak. Die artikel kulmineer in 'n beskrywing van hoe een van die navorsers 'n voorbeeld van sy eie onlangse homiletiese navorsing rakende profetiese prediking in 'n konteks van armoede interpreteer, wanneer die onderliggende metateoretiese standpunte eksplisiet verreken word.

The importance of reckoning with metatheoretical assumptions in preaching and scientific research in homiletics. This article forms part of the second phase of the research project Metatheoretical assumptions in Practical Theology. The research problem has to do with the inability to reckon with shifts in underlying metatheoretical assumptions in the praxis of preaching as well as in embarking on scientific research in the field of homiletics. We focus on the influence of metatheoretical assumptions in the communicative dimension of worldview, hermeneutic notions regarding the communicative field at work in the homiletic process and theoretical notions underlying the researcher's approach in complying with the scientific task of homiletics in a responsible manner. The article culminates in a description of one of the researchers' interpretation of an example of his own recent research in prophetic preaching in a context of poverty when the underlying metatheoretical assumptions were explicitly reckoned with.

\section{Inleiding}

In die tweede fase van die navorsingsprojek Metateoretiese vertrekpunte in Praktiese Teologie word gewerk met die vraag rakende die invloed van metateoretiese faktore op die praksis van vakspesifieke navorsing, in hierdie geval toegepas op prediking en ook op die wetenskaplike benaderingswyse tot die navorsingsveld van Homiletiek.

Pieterse (2005:110) beklemtoon byvoorbeeld die belang van die teologie van die prediker om die evangelie oortuigend te preek. In die postmoderne klimaat en postapartheidsituasie is sommige predikers skynbaar nie meer seker of die prediking van die evangelie effek het en of dit nog aanvaarbaar is om die verhouding tussen God en die mens, en die werking van God in mense en die samelewing, met oortuiging te preek nie. Die vraag wat in hierdie opsig gevra kan word, is in hoe ' $n$ mate ' $n$ gebrek aan bewussyn en verrekening van die element van verandering in die metateoretiese onderbou van die prediker, aanleiding kan gee tot gebrekkige oortuigingskrag wanneer gepreek word. Die teoretiese argument waarmee in hierdie navorsingsprojek gewerk word, is juis dat'n gebrekkige uitspel van en verantwoording ten opsigte van die eie metateoretiese onderbou en die veranderinge wat in die hedendaagse konteks in hierdie onderbou kan intree, die persoon wat in God se diens handel, koers kan laat verloor in 'n see van moontlikhede. 'n Prediker wat meegesleur word deur kritiek teen assertiewe prediking waarin die gesag van die Skrif misbruik word om menslike voorkeure tot absolute waarhede te verhef, kan volgens die rasionaal van bogenoemde teoretiese argument weens 'n gebrek aan verrekening van die impak van hierdie veranderende konteks, in twyfel verval en die gesag van die prediking in sy of haar preek-praksis in gedrang laat kom. 
Ook in die wetenskaplike benaderingswyse tot die navorsingsveld van Homiletiek sou 'n gebrekkige verrekening van verskuiwinge (of verstarring) wat in die metateoretiese onderbou kan intree, 'n navorser in gepolariseerde en eensydige denke kan vasvang. Sedert die Tweede Wêreldoorlog het daar 'n kenmerkende antroposentriese wending in die teologie en ook in Homiletiek plaasgevind (vgl. Cilliers 2009:5; Heitink 1999:110). Hierdie wending is in wese 'n reaksie teen 'n soort teologie waarin daar in die verlede te maklik en op 'n oorvereenvoudigde wyse in die naam van God vaste, absolute uitsprake gemaak is (asof dit volgens sy Woord is), terwyl dit in werklikheid blyk dat daar met menslike, feilbare interpretasies gewerk word waarin die kompleksiteit van die konteks waarin die menslike lewe ontplooi, nie verreken word nie. In die Homiletiek het hierdie wending veral tot uitdrukking gekom in 'n drieledige verskuiwing van die teks na die hoorder, van eksegese na hermeneutiek, en van Christologie na Pneumatologie (Douma 2000:49). Wanneer 'n navorser nie die invloed van hierdie wendinge op sy metateoretiese onderbou bewustelik verreken nie, sou gevra kan word in hoe 'n mate hy of sy meegesleur kan word deur eensydige of reaktiewe denkontwikkeling. Cilliers (2009:5) dui byvoorbeeld aan hoe homiletiese teorieë in hierdie konteks van wendinge meestal slinger tussen 'n (oor)beklemtoning van óf die openbaringsmoment óf die eksistensiële hoorderskonteks, dikwels in navolging van óf Barthiaanse óf Schleiermacheriaanse sentimente.

Die doel van hierdie navorsingsartikel is dan om die eie Reformatoriese metateoretiese onderbou waarmee die navorsingsveld van Homiletiek benader word, uitdruklik uit te spel en om tot ' $n$ verantwoording daarvan te kom ten opsigte van die invloed wat dit kan uitoefen in die konteks van wendinge in die denkklimaat, leefwêreld en kultuur waarin die wetenskaplike taak uitgevoer moet word.

Vir hierdie doeleindes word gebruik gemaak van Osmer (2008:58) se definisie van die elemente waaruit 'n metateoretiese perspektief saamgestel is: 'A metatheoretical perspective thus is composed of the assumptions about reality, knowledge and science that transcends particular research projects and theories.' In die loop van hierdie navorsingsartikel word die eie metateoretiese perspektief waarmee die vakgebied van Homiletiek benader word, uitgespel en verantwoord ten opsigte van:

- die werklikheidsbeskouing waarmee daar op die navorsingsveld van Homiletiek gefokus word;

- die onderbou rakende die hermeneutiese beskouing wat nodig is om tot' $n$ verstaan en ' $n$ verantwoordelike inrigting te kom van die verhouding tussen die kommunikatiewe elemente wat ter sprake kom in die homiletiese proses;

- die wetenskapsteoretiese benadering waarmee die navorsingsveld van Homiletiek op 'n wetenskaplike verantwoorde wyse ondersoek kan word.

Die navorsingsartikel mond uit in 'n voorbeeld van hoe die uitspel van die eie metateoretiese beskouing die aanpak van 'n navorsingsprojek in Homiletiek op verantwoordelike wyse tot ontplooiing kan laat kom. Die navorsingsprojek waarvan hier sprake is, ondersoek die manier waarop die prediker die gebeure van die dag kan lees ten opsigte van die wyse waarop God daarin werksaam is, met die oog op aktuele en profetiese prediking.

\section{Die werklikheidsbeskouing waarmee op die navorsingsveld van Homiletiek gefokus word}

Kragtens die aard van prakties-teologiese wetenskapsbeoefening (wat ten nouste met die beskrywing, verklaring en verandering van die aksie/handelingselement van dit wat ondersoek word, te doen het) (vgl. Heitink 1999:7, 126), is 'n navorsingsprojek wat vanuit hierdie vakgebied onderneem word, op die gebeurlikheidsdimensie in die waarneembare werklikheid van menslike handelinge, in die bepaaldheid daarvan deur die Goddelike werking in die Evangelie, gerig. In 'n navorsingsprojek wat op die vakgebied van Homiletiek aangepak word, word daar bepaald ingefokus op die kommunikatiewe gebeure waarvan daar in die gebeurlikheidsdimensie van die werklikheid sprake is. Die kommunikatiewe gebeure waarvan daar in die homiletiese proses sprake is, vind in ' $n$ bepaalde ruimte plaas waarin die bybelse teks, die prediker en die hoorders in verbinding met mekaar gebring word. Daar is van 'n openbare ruimte sprake waarin daar ' $n$ woord gerig word tot ' $n$ bepaalde adres van mense wat in bepaalde omstandighede gemeenskaplik verkeer. In die uitspel van die werklikheidsbeskouing behoort daar ook met die temporele aspek van die gebeurlikheidsdimensie rekening gehou word. Die hoorders tot wie die homiletiese woord gerig word, het 'n verlede, hede en toekoms. In 'n werklikheidsbeskouing is daar sprake van 'n beskouing oor die manier waarop die oorsprong, voortgang en toekoms van die mense wat by die kommunikatiewe proses betrokke is, in verbinding gebring kan word met die handelinge van God. In 'n werklikheidsbeskouing word daar ook met bepaalde persepsies gewerk oor die verhouding tussen die kontemporêre hoorders en die elemente van kontinuïteit en diskontinuïteit; waarmee hulle verbind is aan voorafgaande geslagte van gelowiges, selfs so ver terug as die eerste lesers en/of hoorders tot wie die bybelse teks oorspronklik gerig is.

In 'n werklikheidsbeskouing wat in die Reformatoriese denkklimaat gebore word, staan die beskouing sentraal dat die kommunikatiewe gebeure waarvan daar in prediking sprake is, behels dat God op 'n lewenskragtige manier aan die Woord kom. Daar word kennelik met ' $n$ teosentriese vertrekpunt in die ontketening en voleindiging van die kommunikatiewe proses gewerk. Volgens Cilliers (2009:3) doen die Woord volgens Reformatoriese belydenis altyd wat dit sê. Daarom is die bybelse teks nie bloot informatief nie, maar inderdaad ook performatief. Die Woord (vgl. die Hebreeuse begrip dabar) dui nie bloot op 'iets' nie, maar is self 'n gebeure, 'n heilsgebeure. In die Woord kom God sélf na ons toe, is Hy sélf die Woord, die Skeppings- en Herskeppingswoord, wat nie alleen alles wat bestaan tot stand geroep het nie, maar ook die dooies tot lewe roep (Joh 1:1-3; Rom 4:17). Dit wat tydens prediking gebeur wanneer God aan die Woord kom, is vergelykbaar met die lewenskragtige gebeure wat plaasvind wanneer 
blindes sien, dowes hoor, kreupeles loop en dooies opgewek word. Die ruimte waarin die kommunikatiewe proses plaasvind, word gesien as 'n verbondsruimte waarin God Hom met sy hele wese verbind aan die mense waaroor $\mathrm{Hy}$ hom ontferm en waar daar verwag kan word dat mense so 'n God met hulle hele hart en siel en al hulle kragte sal liefhê. Dit is 'n ruimte waarin die Woord ' $n$ tweeledige uitwerking het. Dit is 'n ruimte waarin die reuk van die lewe ontsluit word vir diegene wie se harte oopgemaak is om die rykdom van verbondseën te ontvang. Dit is 'n ruimte waarin 'n reuk van die dood opgaan vir diegene wat hardnekkig hulle harte verhard teen die genade van God (2 Kor 2:16). Wat die temporele aspek aanbetref, word daar in die reformatoriese werklikheidsbeskouing met die vertrekpunt gewerk dat die hoorders se ontstaan, voortgang en voleinding trinitaries geanker is die skeppende, verlossende en voleindigende werk van die Vader, Seun en Heilige Gees. Die kontinuïteit tussen die bybelse teks, en daarmee saam die aktualiteit van prediking in kontemporêre konteks, is daarin geleë dat die God wat vandag en gister en tot in ewigheid dieselfde is, Hom met dieselfde trou verbind aan hedendaagse gelowiges as wat dit met die oorspronklike gelowiges die geval was.

Weens die wendinge wat daar plaasgevind het in die wêreld waarin die roeping om te preek en om prediking wetenskaplik te ondersoek, uitgeleef moet word, word die tradisionele reformatoriese benadering met alternatiewe benaderings tot die gebeurlikheidsdimensie van die werklikheid gekonfronteer. Wanneer die immanente aspek van God se betrokkenheid by werklikheid, soos in die geval van 'n panenteïstiese benadering, beklemtoon word, sou dit verreikende gevolge inhou vir die manier waarop die gebeurlikheidsdimensie beskou word. Wanneer panenteïsme langs die weg van prosesteologie gekanaliseer word, word die Goddelike wese getipeer asof dit afhanklik van die skepping sou wees. Die Goddelike agent se werksaamheid word as non-intervensie getipeer. Die skeppingshandeling word geïnterpreteer as 'n handeling van kenosis (selfontlediging). Die Goddelike handeling gaan met selfbeperking gepaard sodat daar aan die skepping ruimte vir selfverwesenliking gegee word. Die implikasie van hierdie beskouing is dat die outonomiteit van die skepping gerespekteer word en dat die Goddelike kwesbaar word en in 'n sekere sin selfs 'afhanklik' van die skepping raak (vgl. Barrett 2000:314; Pope 2007:86).

Wanneer die kommunikatiewe gebeure waarvan daar in die gebeurlikheidsdimensie sprake is, vanuit bogenoemde invalshoek benader word, sou dit verreikende implikasies inhou vir die manier waarop prediking ingeklee word, en die navorsingsveld van Homiletiek beskryf word.

Wanneer daar byvoorbeeld vanuit 'n navorser of prediker se metateoretiese onderbou 'n konnotasie van non-intervensie aan die Goddelike handelingspraksis gekoppel word, sou daar in die manier waarop prediking benader word in meer non-direktiewe taal gepraat word oor die goddelike betrokkenheid. Predikers sou dan baie sensitief wees om absolute uitsprake te maak, waardeur 'n assosiasie van manipulasie en onbehoorlike druk gewek kan word.
Homiletiese teorie-vorming sou dan 'n meer antroposentriese swaartepunt verkry. Selfaktualisering, ruimte vir menslike kreatiwiteit en vryheid om na gelang van omstandighede te ontwikkel, sou dan die sleutelgedagtes wees in die manier waarop die kommunikatiewe verhouding tussen teks, prediker en hoorder gevisualiseer word.

Wanneer ' $n$ navorser sy of haar metateoretiese onderbou ten opsigte van werklikheidsbeskouing bewustelik uitspel en dit vergelyk met 'n alternatiewe benaderingswyse tot die gebeurlikheidsdimensie, kan verantwoording gedoen word van moontlike leemtes, en eensydighede en ondeurdagte reaksies wat daar met verloop van tyd in die eie benadering kon ontwikkel. Die moontlikheid dat antropologiese faktore in die eie benadering onderontwikkeld en oorvereenvoudigend hanteer is, kan dan byvoorbeeld verreken word.

\section{Metateoretiese onderbou rakende die hermeneutiese beskouing}

In hierdie gedeelte van die navorsingsartikel word die onderbou rakende die hermeneutiese beskouing wat nodig is om tot ' $n$ verstaan en ' $n$ verantwoordelike inrigting te kom van die verhouding tussen die kommunikatiewe elemente in die homiletiese proses, bespreek. In die kommunikatiewe gebeure wat tydens prediking plaasvind, is daar sprake van 'n hermeneutiese proses waardeur die proses van verstaan en die wisselwerking tussen bedoeling (boodskap) en die mate waarin dit korrespondeer met die betekenis wat deur die leser of hoorder van 'n teks vanuit die eie verstaanshorison daaraan toegeken word, ter sprake kom. 'n Navorser in Homiletiek behoort ook rekening te hou met hermeneutiese elemente soos die eie voorverstaan in die uitvoer van die wetenskaplike taak wat onder andere behels om teorieë te ontwerp vir die interpretasie van en strategieë met die oog op die inrigting van die verhouding tussen kommunikatiewe elemente in die homiletiese proses.

Die wendinge wat in die tweede helfte van die 20ste eeu in die landskap van homiletiese praksis en navorsing ingetree het, het onder andere te doen met teoretiese besinning oor die proses van verstaan (Hermeneutiek), soos dit onder andere uit taalteoretiese besinning blyk. Teenoor die gedagtegang van die Positivisme dat die waarheid 'n objektiewe werklikheid is, wat buite ons is, en dat daar deur logiese, rasionele denke in lyn gekom moet word met die objektiewe waarheid in die werklikheid, staan die beskouing van Gadamer waarin verstaan van 'n teks uit die verlede nie losgemaak kan word van die konteks waarin die leser hom of haar bevind nie. Dit het die implikasie dat betekenis as veranderlik gesien word. Iedere veranderde konteks waarmee die leser die teks benader, het ' $n$ invloed op die verstaan van die teks en die betekenis wat (deur die leser) aan die teks geheg word. Om die hermeneutiese proses bloot op 'n liniêre wyse in te rig by wyse van eenrigtingverkeer vanaf die teks na die leser (hoorder), sou dus op 'n oorvereenvoudiging van 'n komplekse proses neerkom. Verklaring vind eerder plaas in 'n hermeneutiese spiraalgang bestaande uit die verskillende historiese kontekste van die teks aan die een kant en die 
leser aan die ander kant, waartussen daar heen en weer beweeg word in die proses van ontluikende verstaan. Die hermeneutiese proses word nooit voltooi nie, want betekenis is nie ' $n$ vaste objek nie, maar ' $n$ proses waarin dit in elke nuwe historiese konteks van die betrokke lesers opnuut deurbreek. Elke historiese konteks vorm sy eie verstaanshorison. Daar is ' $n$ vreemdheid aan die teks vir die eietydse leser. Die leser se interaksie met die teks verbind die wêrelde van teks en leser, sodat die verstaanshorisonne van elkeen effens oor mekaar skuif en verstaan moontlik word. Ware hermeneutiese verstaan geskied juis in die konfrontasie tussen ons vooroordele (die wyse waarop ons dinge sien en die hoek waarmee ons na die wêreld kyk), en die vreemdheid van die teks se sieninge (Johnson 1990:64 e.v.; Krabbendam 1984:539; Pieterse 2002:92).

Die implikasies in hierdie verskuiwing van fokus ten opsigte van die hermeneutiese proses, hou vir die inrigting van prediking ingrypende implikasies in. Die verstaansproses kan dan nie meer gesien word as die oordra van 'n vooraf-geformuleerde, tydlose waarheid wat op 'n liniêre, ongekompliseerde wyse vanuit die teks op die hoorder toegepas word nie. Verskillende predikers beklemtoon in verskillende tye verskillende aspekte van dieselfde teks. In die gerigtheid van die teks word dan daarmee rekening gehou dat verstaan deurbreek in die bepaalde konteks waarin die hoorder verkeer. Verstaan is nie iets wat die hoorder bloot as ' $n$ onbevange ontvanger in besit neem nie. Verstaan is eerder iets waaraan die hoorder meewerk. In die prediker en die hoorders se konteks moet daar ook mee rekening gehou word dat daar elemente van voorverstaan en bevooroordeeldheid kan wees wat ' $n$ nuwe verstaan van die betekenis van die teks in 'n mindere of meerdere mate kan beïnvloed.

Wanneer daar 'n gebrekkige verantwoording plaasvind ten opsigte van die implikasies van die metateoretiese onderbou waarmee daar gewerk word met die oog op die inkleding van die verstaansproses, kan die klem op die teks alleen as uitgangspunt vir die ontvangs van betekenis deur die leser gelê word. Vanuit hierdie invalshoek verskaf die teks self die betekenis, terwyl die leser se betekenisgewing nie bewustelik op 'n teoretiese wyse aandag ontvang nie. Aan die ander kant kan die metateoretiese invalshoek waarmee gewerk word, alle klem op die leser as uitgangspunt lê. Hierdie benadering kan daarop uitloop dat die leser betekenis gee, terwyl die teks as betekenisgewer op die agtergrond verdof. Hierteenoor pleit Pieterse (2010:2) vir 'n benadering waarin 'n dialektiek tussen teks en leser help om die spanning tussen teks en leser 'n vrugbare spanning te maak. Deur die vooroordele van die eie tyd (voorafmenings) en die vreemdheid van die teks wat die leser in interpretasie ontmoet, vind 'n kritiese konfrontasie tussen leser en teks plaas. Dit is juis in hierdie heen-en-weer van die interpreterende konfrontasie waar die verstaan uiteindelik daag. Die spanning tussen die eie en die vreemde deur die verstaansproses heen bewerk 'n horisonversmelting, waar die teks se betekenis vir die eie tyd verstaan kan word.

Wanneer 'n metateoretiese onderbou, wat sy vertrekpunt in die Reformatoriese benadering vind, verantwoording wil doen van 'n toereikende visie op die hermeneutiese proses, moet volledig met die werkingskrag wat in die teks geleë is, sowel as die konteks van die hoorder en/of leser en die implikasies daarvan vir betekenisgewing, rekening gehou word. In 'n pneumatologiese benadering word die betekenisgewende en/of betekenisomhelsende aktiwiteit van die hoorder en/of interpreteerder altyd beskou vanuit die mate waarin dit spreek van die gesindheid van Christus. Die gesindheid van Christus is juis om alleen dit wat die Vader aan Hom toevertrou het, te doen en om in die proses niks daarvan weg te neem nie en niks daarby te voeg nie.

\section{Die wetenskapsteoretiese benadering waarmee die navorsingsveld van Homiletiek op 'n wetenskaplike verantwoorde wyse ondersoek kan word}

Wanneer daar sprake is van 'n wetenskaplike gerigtheid op die gebeurlikheidsdimensie van die werklikheid, met inbegrip van die verstaansprosesse wat hierin ter sprake kom, kan daar met die volgende werksdefinisie vir homiletiese wetenskapsbeoefening gewerk word:

Homiletiek is 'n wetenskaplike studie van die kommunikatiewe gebeure tussen die Bybelse teks, die hoorders en die prediker. Vanuit die Reformatoriese vertrekpunt word die invalshoek van die navorser daardeur bepaal dat die eie vooroordele onder leiding van Gees van Christus geplaas word sodat met onderskeidingsvermoë, liefde vir God en sy mense en diensbaarheid ondersoek kan word in watter mate God aan die woord kom of verhinder word om aan die woord te kom in die konteksgerigtheid van die Woord.

In 'n vorige fase van die navorsingsprojek waarvan hierdie artikel deel vorm, is 'n model ontwerp waarin gepoog is om die metateoretiese vertrekpunte waarmee 'n reformatoriese

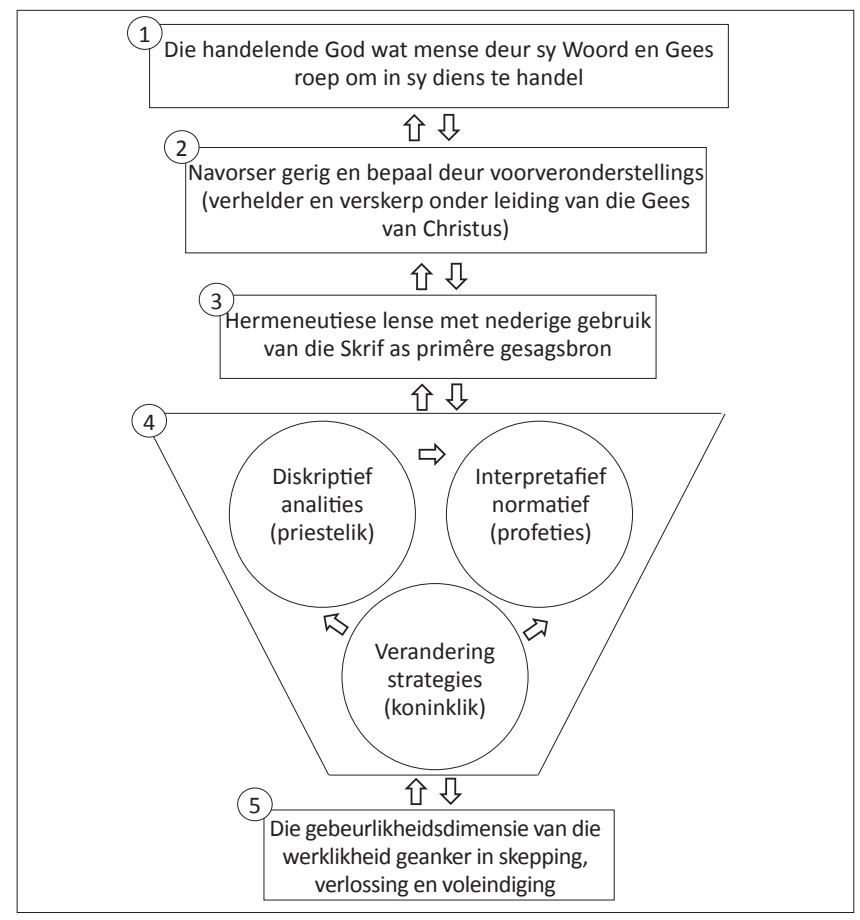

FIGUUR 1: Hermeneutiese model vir 'n reformatoriese wetenskaplike se benadering tot die navorsingsterrein van Homiletiek. 
wetenskaplike die navorsingsterrein benader en die wetenskaplike taak uitvoer, te visualiseer:

Met die oog op 'n visualisering van die manier waarop metateoretiese vertrekpunte die aanpak en uitvoer van 'n wetenskaplike projek stuur en rig, kan die sleutel elemente in bogenoemde model ten opsigte van 'n homiletiese navorsingsprojek soos volg ingeklee word:

- Die handelende God roep mense deur sy Woord en Gees om in sy diens te handel, onder andere as prediker wat geroep word om die Woord te bedien of as navorser wat geroep word om prediking wetenskaplik te ondersoek. Die navorser in Homiletiek sal dus nie alleen in die handelingspraksis wat ondersoek word, vra in watter mate dit wat in mense se lewens gesien word, die werk van die Drie-enige God weerspieël nie, maar sal homself of haarself ook onder leiding van die Gees en Woord van God plaas, ten einde hulle afhanklikheid van sy waarheidoopmakende lig en getroue leiding te erken.

- In 'n pneumatologiese benadering kan bepaaldheid deur voorveronderstellings (bepaaldheid vanweë sieninge wat uit die opvoeding, omgewing, kultuur en die invloed van die tradisie voortkom) ook behels dat dit wat in die kommunikatiewe dimensie van die homiletiese proses ondersoek word deur die oë van Christus en met sy hartsgesindheid waargeneem kan word. Die blikwydte van voorveronderstellings kan verruim word deur te sien hoe lieflik dit is waar die Woord van God onbevange, in interaksie en in lewende kontak met die landskap van die hoorders se konteks skyn. Dit neem egter nie weg dat eensydige persepsies in die voorveronderstellings teenwoordig mag wees nie (bv. 'n teksgesentreerde benadering waarin die lewende aard van die konteks van die hoorder nie verreken word nie) en derhalwe in die loop van die wetenskaplike proses aan kritiese verantwoording oopgestel moet word nie.

- In die aanlê van hermeneutiese lense word die Skrif in nederigheid as primêre gesagsbron gebruik vir die beoordeling van die mate waarin dit wat in die homiletiese praksis waargeneem word, verteenwoordigend is van die wese en doel van prediking. Dit beteken egter nie dat die onvolmaakte interpretasie van die Skrif deur die navorser nie aan kritiese beoordeling onderwerp moet word nie en dat ander bronne (bv. teoretiese bevindings deur menswetenskappe oor die wisselwerking tussen 'n teks, prediker en hoorders) nie 'n wesenlike bydrae kan lewer tot die verstaan van verskynsels in die navorsingsveld nie.

- Dit wat onder leiding van die Gees van Jesus Christus deur die relevante hermeneutiese lense in die ondersoekveld waargeneem word, kan in verbondenheid met Christus analiserend vanuit 'n spiritualiteit van priesterlike bewoënheid beskryf word, en krities-vergelykend, prinsipieel en normatief vanuit 'n spiritualiteit van profetiese onderskeidingsvermoë geïnterpreteer en gestruktureer word met die oog op strategiese verandering vanuit 'n spiritualiteit van koninklike diensbaarheid (Osmer 2008:33, 81, 135, 183). Die aanpak van hierdie drieledige wetenskaplike taak op die navorsingsterrein van Homiletiek sal behels dat die wese van die wetenskaplike bydrae wat gemaak kan word, gevisualiseer word as 'n intense kritiese gerigtheid daarop dat niks by die Woord bygevoeg word, of daarvan weggeneem word nie, 'n liefdevolle bewoënheid oor mense wat sonder die Woord of met 'n vervalste Woord in die duisternis sit, en 'n gewillige diensbaarheid om die Woord sy gang te laat gaan.

- In die gerigtheid van die navorser op die kommunikatiewe aspek van 'n gebeurlikheidsdimensie word daar gefokus op menslike handelinge (van prediker en hoorders), in die besonder in die geloofsverbondenheid en/ of onversoendheid daarvan met betrekking tot die trinitariese optrede van God wat die lewe van die gelowige deur die kragtige werking van sy Woord omraam deur sy skeppende, verlossende en voleindigende handelinge.

\section{'n Voorbeeld van hoe metateoretiese onderbou die inrigting en ontplooiing van 'n navorsingsprojek in Homiletiek rig Die noodsaak van profetiese prediking in 'n
konteks van armoede: Inleiding}

Binne die Reformatoriese metateoretiese onderbou soos ons dit verstaan en beskryf, word daar nou 'n voorbeeld gegee van hoe die prediker die eietydse gebeure kan probeer lees as God se werking in die alledaagse gebeure in ons konteks. Die voorbeeld gaan oor die noodsaak van profetiese prediking in ons konteks van armoede en die sosiaal-politieke faktore wat die konteks beïnvloed. Die gedagte is dat nadat die eksegese van die teksgedeelte gedoen is (in hierdie geval prediking uit Amos, veral hoofstuk 5 en met besondere fokus op 5:21-24, as basisteorie vir profetiese prediking), die prediker ook die konteks en die gebeure van God se werking in ons konteks moet kan lees. Dit is nodig vir die hermeneuse sodat aktuele en profetiese prediking kan geskied wanneer die teks sigself in ons konteks uitspreek. Die roeping tot profetiese prediking is dan ook die eerste element in ons model van ondersoek; die handelende God wat mense deur sy Woord en Gees roep om in sy diens te handel.

Hierdie navorsers word ook gerig en bepaal deur sekere teologiese voorveronderstellings onder leiding van die Gees van Christus. Soos ons dit hierbo gestel het, geskied hierdie gedeelte binne daardie raamwerk, naamlik dat die kommunikatiewe gebeure waarvan daar in die homiletiese proses sprake is, plaasvind in 'n bepaalde ruimte waarin die bybelse teks, die prediker en die hoorders in verbinding met mekaar gebring word. Daar is van 'n openbare ruimte sprake waarin daar ' $n$ woord gerig word tot die adres van mense wat gemeenskaplik in bepaalde omstandighede verkeer. In 'n werklikheidsbeskouing word daar ook met bepaalde persepsies gewerk oor die verhouding tussen die kontemporêre hoorders en die elemente van kontinuïteit en diskontinuitteit waarmee hulle verbind is aan voorafgaande geslagte van gelowiges, selfs so ver terug as die eerste lesers en/of hoorders tot wie die bybelse teks oorspronklik gerig is. In 'n werklikheidsbeskouing wat in 'n reformatoriese 
denkklimaat gebore word, staan die beskouing sentraal dat die kommunikatiewe gebeure waarvan daar in prediking sprake is, behels dat God op 'n lewenskragtige manier aan die Woord kom. Daar word met 'n teosentriese vertrekpunt in die ontketening en voleindiging van die kommunikatiewe proses gewerk. Die bybelse teks is nie bloot informatief nie, maar ook performatief. Die Woord in die teks geskied as 'n Woordgebeure, 'n heilsgebeure (vgl. Pieterse 1979:112-115). God sélf kom in die Woord na ons toe en spreek ons aan. Die ruimte waarin die kommunikatiewe proses plaasvind, word gesien as 'n verbondsruimte waarin God Hom met sy hele wese verbind aan die mense waaroor Hy Hom ontferm, en waar daar dan verwag kan word dat die mense so 'n God met hulle hele hart en siel en al hulle kragte sal liefhê. Dit is ' $n$ ruimte waarin die Woord ' $n$ tweeledige uitwerking het; diegene met ontvanklike harte ontvang die rykdom van verbondseën, maar 'n oordeel hang oor diegene wat hardnekkig hulle harte verhard teen die wil van God. Wat die temporele aspek betref, word daar in die Reformatoriese werklikheidsbeskouing vanuit die vertrekpunt gewerk dat die hoorders se ontstaan, voortgang en voleinding trinitaries geanker is in die skeppende, verlossende en voleindigende werk van die Vader, Seun en Heilige Gees. Die kontinuïteit van die bybelse teks, en daarmee saam die aktualiteit van prediking in 'n kontemporêre konteks, is daarin geleë dat die God wat vandag en gister en tot in ewigheid dieselfde is, Hom met dieselfde trou verbind aan hedendaagse gelowiges as wat dit met die oorspronklike gelowiges die geval was.

Die vraag in hierdie paragraaf is: Waarmee is God werkend besig in die eietydse gebeure in ons land? Hoe moet die prediker dit lees in die lig van die Skrif? Eers sal ons voorbeelde gee van predikers wat onder leiding van die Gees die gebeure van hulle tyd kon lees en interpreteer, oftewel die werking van God in hulle konteks verstaan het en die prediking van die Skrif as profetiese prediking hanteer het. Karl Barth, Beyers Naudé en Desmond Tutu se werk en standpunt-inname word kortliks bespreek. Daarna sal eietydse stemme oor die konteks van armoede, veral onder die jeug, aan die orde gestel word. Laastens volg eksegese van Amos, veral van Amos 5:21-24, met die oog op profetiese prediking in ons tyd.

\section{Karl Barth, Beyers Naudé en Desmond Tutu as verteenwoordigers van profetiese prediking}

\section{Karl Barth en die Eerste Wêreldoorlog}

Die teologiese opleiding wat Karl Barth (gebore in 1886) ontvang het, het nog in die teken gestaan van die blymoedige optimisme van die negentiende eeuse liberale teologie (vgl. Barth 1947). In dié tyd het mense in Europa gedink dat die wêreld steeds tot 'n hoër volkomenheid sou ontwikkel. Hierdie wêreldbeskouing het God as 'n vriendelike en goeie God gesien, en die mens as 'n byna goeie wese. In 1911 word Barth predikant van Safenwil in die Switserse Alpe en in 1914 breek die Eerste Wêreldoorlog uit. Die optimistiese wêreldbeskouing van die laaste 100 jaar het toe plotseling en radikaal inmekaar gestort. Barth besef dat prediking in die raamwerk van daardie teologie nie meer werk nie.
Weens die verleentheid van die prediker in daardie vreeslike tyd begin hy die briewe van Paulus en later veral die brief aan die Romeine met die nuwe oë van sy nuwe konteks lees (Bronkhorst 1953:13). Die resultaat hiervan was die publikasie van Der Römerbrief (Barth 1919).

In die publikasie van sy eerste lesingbundel vertel hy van sy worsteling ten opsigte van die nood van die tyd en die belofte van die Christelike verkondiging (vgl. Barth 1922). Wat is die bedoeling van alles wat in hierdie bloedige slagtings met mense gebeur? In die lig van sy vrae het hy geworstel met die Skrif en met die vraag: Wat moet iedere Sondag opnuut weer gepreek word? Ons moet besef dat die brief aan die Romeine is sy tyd histories-krities gelees is:

Historisch: men vroeg zich af, wat Paulus aan mensen van zijn dagen had willen zeggen. Men bestudeerde de inhoud der woorden, zocht naar parallelen uit de letterkunde en de andere godsdiensten van die dagen, probeerde de Romeinenbrief te reconstrueren, zoals een kunsthistoricus de Nachtwacht van Rembrandt of een ander vervallen kunstwerk uit het verleden wil schoonmaken en oppoetsen. En als men dit bereikt had, las men kritisch. Man gaf - vrijmoedig - zijn oordeel; zowel over de tekst als over de inhoud. Allerlei verzen, die Paulus onmogelik geschreven kon hebben op grond van allerlei hooggeleerde overwegingen, werden als onecht terzijde geschoven, terwijl andere woorden als verouderd en alleen maar in de situatie passend, op pensioen worden gesteld. (Bronkhorst 1953:14)

Die krag van die Woord is hiermee mak gemaak. Want waarmee die uitleggers van destyds nie mee saam kon stem nie, is eenkant gesit asof Paulus dit nie gesê het nie, of asof hy dit ten onregte gesê het. Maar Barth kom na die Skrif in die konteks van die katastrofe van die oorlog met die vraag: Wat wil God vir ons hierdeur, ook ten opsigte van hierdie soort wêreldbeskouing en teologie, sê? Geleidelik dring dit tot hom deur. God is God (vgl. Barth 2004:16). Sy lees en interpretasie van sy konteks in die lig van die brief aan die Romeine bring hom tot ' $n$ nuwe verstaan van God en mens. Barth ontdek nuwe klanke in Romeine. Dit gaan hier nie oor 'n goedige God nie, maar oor 'n heilige en regverdige God. In hierdie klanke hoor Barth die geweldige onderskeid tussen God, wat in die hemel is, en die mens, wat op die aarde is. God is die Gans Andere. Daar is 'n oneindige kwalitatiewe verskil tussen God en mens. Die mens is 'n verlore sondaar totdat hy of sy die Woord in al sy krag en bedoeling hoor, en deur God tot ' $n$ radikaal nuwe mens verander word. In die katastrofe van die verwoestende oorlog leer hy God se bedoeling daarmee verstaan. Al die mens se hoogmoed en eie krag word met een beweging weggevee en uit die puin kom die boodskap: God is die ware God van die Skrif en die mens is mens in al sy broosheid en verlorenheid. Dié boodskap begin hy profeties aan die mense van sy tyd en op kritiese wyse teenoor die teologie van sy dag verkondig. Hy onderskei tussen religie en godsdiens. Religie probeer van onder af iets oor God sê. Dit is natuurlike godsdiens. Ware godsdiens ontstaan vanweë die openbaring van God in die Skrif. Ons kan die boodskap alleen van bo af, van God self, hoor, van God wat Hom in Jesus Christus genoegsaam openbaar het. Barth wys telkens op die gode van die wêreld wat mense aanhang en roep mense op tot gehoorsaamheid aan die God van die Bybel (vgl. Barth 2004:12-45). 


\section{Beyers Naudé en sy breuk met apartheid}

Beyers Naudé (gebore in 1915) kom uit 'n predikantfamilie in die NG Kerk wat hulle voluit vir die Afrikanersaak beywer het. Hy het dieselfde pad gevolg. Soos sy kerk, was hy 'n ondersteuner van die apartheidsbeleid van die regering. Toe hy predikant in Potchefstroom word, kom daar egter ' $n$ wending. Hy is veral in hierdie tydperk (1955-1959) gevorm tot sy latere standpunt teen apartheid (Berkhof, Bethge \& Boesak 1985:15). In Potchefstroom woon hy die Gereformeerde Ekumeniese Sinode by wat sy blik verbreed. Daar word hy deur jong Wit sendelinge, wat hy as studenteleraar in Pretoria leer ken het, gekonfronteer met die negatiewe effekte van die groepsgebiedewet en ander apartheidswetgewing op mense (Berkhof et al. 1985:15). En in Potchefstroom leer hy by die lidmate van die Gereformeerde Kerke wat sy Bybelstudies en eredienste bywoon, om die Woord van God op 'n bepalende, nuwe manier eksistensieel te verstaan (Berkhof et al. 1985:16).

Kort na sy aanvaarding van die beroep na Aasvoëlkop in 1960 vind Sharpeville plaas. 'n Ekumeniese beraad van die Wêreldraad van Kerke word in dié krisistyd by Cottesloe gehou. Die verklaring van die afgevaardigdes uit die NG Kerk en Hervormde Kerk by dié beraad is so Bybels radikaal teen die idee van apartheid dat die Eerste Minister (Verwoerd) hulle tot orde roep. Net Naudé weier om die verklaring terug te trek (Berkhof et al. 1985:17). Met sy verkiesing as moderator van die Sinode van die NG Kerk van Transvaal in 1962 word hy voor 'n beslissende moment gestel. Die kerk eis van hom om as redakteur van Pro Veritate, wat hy twee jaar tevore begin het, te bedank en daardeur sy integriteit ten opsigte van die posisie van die NG Kerk te bewys. Hy weier en bedank in September 1963 as moderator van die kerk. Hy verloor tegelykertyd ook sy predikantsbevoegdheid. Sy afskeidspreek in Aasvoëlkop het die volgende tema gehad: Ons moet God meer gehoorsaam wees as die mense (Berkhof et al. 1985:18).

Met sy Christelike Instituut en die tydskrif Pro Veritate het hy 'n sterk profetiese stem teenoor apartheid laat hoor. Hy was destyds 'n alleenstryder in die Afrikaanse gemeenskap, maar hy het die omstandighede van sy tyd onder leiding van die Gees gelees. Hy het insig ontvang van waarmee God in sy handeling in die situasie van destyds besig was, en hy het die roeping tot profetiese prediking aanvaar.

\section{Desmond Tutu se profetiese stem}

Desmond Tutu (gebore in 1931), tans emeritus-aartsbiskop van die Anglikaanse Kerk, het sy profetiese stem teen apartheid na die opstande in Soweto (1976) laat hoor. Een van die outeurs van hierdie artikel (Pieterse) het meegewerk aan 'n steekproef van twaalf van Tutu se preke en toesprake oor 'n tydperk van 16 jaar. Die gegrondeteorie- (grounded theory) inhoudsanalitiese metode is vir die doeleindes van hierdie ondersoek aangewend (vgl. Pieterse 1995, 2001). Sy boodskap was oor hierdie tydperk steeds dieselfde. Dit was inklusief, Swart en Wit tesame moes bevryding smaak. Die bybelse krag van sy profetiese prediking het uit die ondersoek sterk na vore gekom:
In Tutu's thought salvation is the basic theological concept for his conviction that apartheid will bite the dust ... Salvation (the deed of salvation by Jesus' victory over Evil) is therefore the basic theological concept which functions in the texts we have analysed ... By using the theological concept of salvation as central concept in his thinking and preaching on liberation, Tutu links up with a central concept in the Christian theological tradition. (Pieterse 2001:49-50)

Tutu kan dus gesien word as 'n bybelse prediker wat sy profetiese boodskap op die verlossingsboodskap van die Skrif gebou het. Hierdie grondige vertrekpunt word bewys deurdat hy tot vandag steeds sy stem sonder aansiens des persoons (of regering) laat hoor. Hy het ook die handeling van God in die donkerste situasie van sy gemeenskap gelees, en die roeping aanvaar om profeties daarbinne te preek.

\section{Profetiese prediking, in die lig van bostaande bespreking, sluit ook elemente van pastorale en kerugmatiese prediking in}

\section{Proteste van die armes in ons eie tyd}

In ons navorsingsmodel is daar plek vir ' $n$ kennisname van wat in die werklikheid van ons konteks gebeur. Aan die hand van Osmer se benadering wil ons nou die vraag vra: 'What is going on?' (Osmer 2008:4). In ons konteks is daar in die laaste jare al meer proteste in die townships van die armes oor swak dienslewering en hulle ellendige situasie. Hierdie proteste word telkens deur die polisie onderdruk, soms met geweld. Ten spyte van die 17 jaar waarin die nuwe demokratiese regering aanvoer dat hy aan die kant van die armes is, word die elite steeds ryker en die armes armer (Burger, Louw \& Van der Watt 2010:66). Dit is veral die armes in die townships en plakkerskampe wat verwaarloos word en die onreg van swak dienslewering en ' $n$ hopelose toekoms in die gesig staar. Wat hier volg is 'n baie kort verslag (vanweë gebrek aan ruimte) van priesterlike luister deur middel van deskriptiefanalitiese ondersoek.

Manala (2010) het 'n indringende sosiale analise gedoen oor swak dienslewering in die arm buurte. Hy toon aan dat die proteste in die swart woonbuurte sedert 2004 al meer geword het (Manala 2010:521), en verskaf op grond van ondersoeke die volgende lys van oorsake:

From the abovementioned findings, it seems that the core causes of service delivery protests are the continuing poverty, unemployment, inabiblity of the ANC to implement policy and lack of participation and say by communities in local government structures and systems. (Manala 2010:522)

Verder toon hy aan dat die hebsug en korrupsie van munisipale amptenare aan wie geld toevertrou is, die lewering van dienste in die wiele ry. Hy haal voorbeelde aan van 'n township waar daar byvoorbeeld in 2008 laas vars water beskibaar was, omdat die helfte van die geld vir watervoorsiening verdwyn het 'to pay municipal employees' salaries, creditors and general expenses. The question is: what became of the budget for salary payments?' (Manala 2010:523).

'n Kwalitatiewe ondersoek met 'n gestruktureerde onderhoudskedule onder werklose jongmense deur een van die skrywers (Pieterse) in Januarie 2011 bevestig 
sommige van Manala se bevindings. Die onderhoudskedule waarin die respondente hulle antwoorde op die vrae moes neerskryf, is in Mamelodi (Tshwane) en Zamdela (Sasolburg) gebruik. Jongmense wat tou gestaan het waar ' $n$ werkgewer mense soek, is deur my veldwerkers van agter in die tou af gevra om dit in te vul. Nadat 18 respondente gevind is, is die opname gestaak (vir 'n kwalitatiewe ondersoek is dit voldoende). Die groep bestaan uit agt vroue en 10 mans, en het 'n gemiddelde ouderdom van 23 en 'n half jaar. Van die 18 is 16 werkloos en twee het tydelike werkies. Twee vrae in die onderhoudskedule is belangrik vir hierdie priesterlike luister na die situasie. Op die vraag oor hulle ervaring van armoede is gebrek aan voedsel, behuising en gesondheidsorg hulle grootste nood. Respondent 8 (Mamelodi) skryf:

I am experiencing difficulties because I am not working and it is difficult for me to get food and to get a better house ... Sometimes I sleep with the empty stomach.

Op die vraag oor wat hulle dink die rede vir die proteste oor swak dienslewering is, het alle respondente min of meer dieselfde rede aangegee. Respondent twee sê byvoorbeeld (Mamelodi): 'Politicians promise poor people proper service delivery when they need our votes during elections, but after they got what they want they disappear.' Respondent 16 (Zamdela) skryf: 'In our township they don't care about people. They look for themselves.' Dit is die refrein van al die respondente oor die swak dienslewering. Hulle voel dat hulle agtergelaat en weggegooi is.

Die interpretatief-normatiewe aspek van die kennisname van wat in ons konteks aan die gang is, noop die prediker om profeties kennis te neem van die stemme wat rondom ons opgaan. Oud-president Nelson Mandela (Mandela 2010:407) skryf al in 1998 in sy outobiografie dat hy geskok is oor vryheidsvegters wat hoë ideale nagevolg het, en so gou verval het in 'personal enrichment ultimately overwhelming them ... (they) deserted the masses of the people and joined the former oppressors, who enriched themselves by mercilessly robbing the poorest of the poor'. Verskeie stemme in ons land gaan die laaste tyd op oor die verwaarlosing van die armes en die arm jeug. Minister Trevor Manuel het op 16 Maart 2011 by ' $n$ seminaar in Kaapstad oor die Verenigde Nasies se millennium-ontwikkelingsdoeleindes vraagtekens geplaas oor die toewyding van sekere van sy kollegas in die ANC om die party se waardes ten opsigte van die versorging van die armes uit te leef (Hartley 2011:1). Hoës uit akademiese, sake en politieke kringe het op ' $n$ armoedekonferensie in Kaapstad, gereël deur die NG Kerk en die Verenigende Gereformeerde Kerk, teen die regering uitgevaar en gesê korrupsie, swart bemagtiging (SEB) en die onbevoegdheid van staatsamptenare en sluwe politici dra regstreeks by tot armoede in die land. Dr. Franklin Sonn het gesê dat hy hom nooit kon voorstel dat die ANC-kamerade so geweldig korrup en so geweldig gierig sou wees nie (Bottomley 2011:1). Me. Kate Robertson, medestigter van die internasionale jeugleierskapsorganisasie One Young World, het in Johannesburg gesê dat jongmense in ons land baie bewus is van die uitdagings wat hulle in die gesig staar, en die middele het om die regering en die sakesektor tot verantwoording te roep. Respondente van alle rassegroepe is in die navorsing waarvan Me. Kate Robertson praat, betrek. Dit is opmerklik dat Suid-Afrikaanse jongmense se bewustheid van kwessies soos maatskaplike verantwoordelikheid en kommer oor korrupsie veel hoër is as dié van Chili, Indië en China (Lamprecht 2011:18). Dr. Ramphele Ramphela het op 'n vergadering van jong leiers in Kaapstad gesê dat die SuidAfrikaanse onderwysstelsel besig is om jongmense van hulle toekoms te beroof (De Wese 2011:4).

Wat hoor die prediker interpretatief-profeties in hierdie deskriptief-analitiese gegewens en in die priesterlike luister en profetiese interpretasie van die stemme wat opgaan oor die woelinge onder ons arm jeug? Waarmee is ons handelende God besig in ons werklikheid en onder ons mense? Is dit nie tyd om koninklik te dink aan strategiese verandering in ons prediking nie? Die verandering lê volgens ons op die terrein van profetiese prediking.

\section{Basisteorie vir profetiese prediking}

'n Mens kan verskeie Skrifgedeeltes eksegeties gebruik om 'n basisteorie vir profetiese prediking te ontwikkel. Ons kies Amos, en veral hoofstuk vyf, met 'n besondere fokus op 5:21-24. Amos is 'n profetiese boek wat God se oordeel oor sosiale onreg aankondig. Die genre van die boek is dus ' $n$ boek met profetiese uitsprake, soms in digvorm, soos gesien kan word in 1:3-2:16; 3:3-8; 7:1-9 en 8:1-3 (König 1974:14). Die skopus van die boek is die beoordeling van menslike optrede met betrekking tot sosiale onreg vanuit God se perspektief (Snyman 1999:1020). Die historiese situasie waarin die profesieë uitgespreek is, is min of meer tussen 765 v.C. en 760 v.C. (Smith 1989:3), tydens die regering van Jerobeam II in die Noordryk. Dit was 'n tyd van voorspoed en weelde (Am 3:15; 4:1; 5:11). Die Israeliete van die Noordryk het seker gevoel van die Here se nabyheid en beskerming. Hulle was immers 'n verbondsvolk (Am 3:1-2; 5:14), daarom ook hulle ywerige godsdienstige lewe (Am 4:4-5). Die besondere situasie van die eerste hoorders was dat hulle sosiale onreg teenoor die armes gepleeg het ten spyte van hulle godsdienstige bedrywighede en hulle teologie (Smith 1989:13). Amos, 'n landbouer, kom van Judea na die Noordryk om God se roeping as profeet te vervul (Polley 1989:3-5). Hy het 'n roeping van God vir die taak ontvang (7:14-15).

In Amos 5:1-17 spreek Amos 'n weeklaag uit oor Israel. Dit is ' $n$ treurlied, wat by begrafnisse gesing word (Smith 1989:177178). In hierdie gedeelte is daar reeds indikatief en belofte opgesluit, en ook dreiging en aanklag (5:6-7). In 5:18-27 word 'n profetiese uitspraak gelewer oor hulle valse hoop oor die dag van die Here wat vir hulle nié verlossing inhou nie, maar duisternis (5:18-20), en word God se afsku van hulle godsdiens sonder sosiale geregtigheid sterk uitgelig (5:21-23) met 'n imperatief tot die doen van geregtigheid $(5: 24)$.

Hoofstuk 5:1-27 vorm die teologiese hoogtepunt asook die strukturele middelpunt van die boek (Snyman 1999:1026). Binne hierdie gedeelte is 5:21-24 die skerp fokus. Alhoewel eksegete verskil oor die eenheid van 5:20-24, vorm 5:21-24 wel 'n 'separate unit' (Polley 1989:154). Die sterkste woorde 
word in 5:21 gebruik ('Ek haat, Ek verafsku julle feeste, ek het niks aan julle feestye nie') en ook in vers 23 oor hulle sang en musiek ('Gee pad voor my met die rumoer van jou gesing; Ek wil nie jou harpmusiek hoor nie'). God verwerp hulle godsdienstige feeste en hulle liturgie. Die eerstepersoonuitsprake van God verleen 'n kragtige verwerping van hulle hoogste uitdrukkings van liefde en toewyding aan God. Dit gaan hier nie eers oor die priesterlike taak om te oordeel of die offers welbehaaglik voor God is nie (Polley 1989:155). Dit gaan oor God se uitspraak deur die woorde van Amos. Godsdiens sonder sosiale geregtigheid is nie aanvaarbaar vir God nie.

Regspraak geskied in die poorte van die stad deur die oudstes. Die regspraak is die praktiese vrug van die reg. Reg of geregtigheid beteken om op te tree ooreenkomstig die aansprake wat ' $n$ bepaalde verhouding op ' $n$ mens maak. Dit is 'n begrip wat 'n verhouding tussen mense of tussen mens en God uitdruk. Geregtigheid geskied wanneer 'n persoon se verhouding met ' $n$ ander persoon in orde is (Snyman 1999:1020). God het 'n verbond met Israel (ook in die Noordryk) gesluit en daarom spreek Amos hulle aan namens die almagtige God wanneer hulle ten spyte van hulle godsdienstige handelinge nie leef volgens die bepalings van die verbond nie.

In Amos 5 is daar indikatief (5:4, 5:6, 5:14), imperatief (5:24) en in Amos 9:11 is daar ' $n$ belofte. Die oordeel is nie finaal nie. As die volk vra na die wil van die Here en hulle bekeer, sal God hulle genadig wees. Ook vir vandag se prediker is die openbaring in Amos, veral 5:21-24, 'n tydige oproep om in ons situasie met die sosiale onreg teenoor die armes te soek na profetiese prediking. Ons bied hierdie uitleg van Amos en die oproep tot profetiese prediking aan met nederige gebruik van die Skrif as primêre gesagsbron.

\section{Slot}

Die empiriese ondersoek is gedoen met ' $n$ kwalitatiewe onderhoudstruktuur onder ' $n$ steekproef van 18 respondente in twee swart woonwyke. Die doel van die ondersoek was om empiries vas te stel hoe arm, werklose swart jong mense die slegte lewensomstandighede van armoede ervaar wat Manala in sy sosiale analise beskryf het (kyk bo). Die bevindinge het aangetoon hoe hopeloos die situasie van armes in ons land is, en hoe dringend die kerk haar profetiese roeping in die prediking moet beskou. Verdere ondersoek word tans deur Pieterse gedoen in 'n gegronde teoretiese inhoudsanalise van preke oor Matteus 25:31-46 as verdere ondersoek in hierdie veld.

\section{Erkenning \\ Mededingende belange}

Die outeurs verklaar dat hulle geen finansiële of persoonlike verbintenis het met enige party wat hulle nadelig kon beïnvloed in die skryf van hierdie artikel nie.

\section{Outeurs bydrae}

F.W.d.W. (Noordwes-Universiteit) en H.J.C.P. (Universiteit van Suid-Afrika) het gelyke verantwoordelikhede gehad het in die skryf van hierdie artikel.

\section{Literatuurverwysings}

Barrett, P.J., 2000, 'Toward a Trinitarian “Theory of Everything”', in C.W. du Toit (ed.), Evolution and creativity - A new dialogue between faith and knowledge, pp. 303-329, Research Institute for Theology and Religion, UNISA, Pretoria.

Barth, K., 1919, Der Römerbrief, Evangelischer Verlag A.G., Zollikon-Zürich.

Barth, K., 1922, Das Wort Gottes und die Theologie, Chr. Kaiser Verlag, München. PMid:18010662 PMCid:1354063

Barth, K., 1947, Die protestantische Theologie im 19, Jahrhundert, Evangelische Verlag A.G., Zollikon-Zürich.

Barth, K., 2004, God is God, Voordrachten 1930-1936, vertl. N.T. Bakker, Kok, Kampen.

Berkhof, H., Bethge, A., Boesak, A. et al., 1985, Met de moed der hoop, Opstellen aangeboden aan Dr. C.F. Beyers Naudé, Ten Have, Baarn.

Bottomley, E-J., 2011, 'ANC kry pak op armoede-konferensie', Sake24, 1 en 17 Maart, bl. 1.

Bronkhorst, A.J., 1953, Karl Barth, Een levensbeeld, Boekencentrum, N.V., 's-Gravenhage.

Burger, R., Louw, M. \& Van der Watt, C., 2010, 'The challenge of poverty and social exclusion in post-apartheid South Africa', in I. Swart, H. Rocher, S. Green \& J. Erasmus (eds.), Religion and social development in post-apartheid South Africa, pp. 61-73, SUN Press, Stellenbosch.

Cilliers, J.H., 2009, 'Skrifbeskouing en oorredingsretoriek: Perspektiewe op performatiewe prediking', Acta Theologica 2009(1), 1-16.

De Wese, M., 2011, 'SA onderwys beroof jonges van toekoms - Ramphele', Beeld, 4 en 22 Maart, bl. 4.

Douma, J., 2000, Veni Creator Spiritus, De meditatie en het preekproces, Kok, Kampen. PMid:10968495

Hartley, W., 2011, 'Manuel questions delivery standards', BusinessDay, 2 en 17 Maart, bl. 1.

Heitink, G., 1999, Practical Theology: History, theory, action domains, Eerdmans, Grand Rapids, MI

Johnson, E.E., 1990, Expository Hermeneutics: An introduction, Zondervan, Grand Rapids, MI.

König, A., 1974, Die profeet Amos, NG Kerk-Uitgewers, Kaapstad/Pretoria.

Krabbendam, H., 1984, 'The new Hermeneutic', in E.D. Radmacher \& R.D. Preus (eds.), Hermeneutics, inerrancy and the Bible, pp. 533-558, Zondervan, Grand Rapids, MI.

Lamprecht, I., 2011, 'Jeug kan stem lekker dik maak, waarsku organisasie, Sake24, 18 en 25 Februarie, bl. 1.

Manala, M.J., 2010, '"A better life for all": A reality or a pipe-dream? A black theology intervention in conditions of poor service delivery in the democratic South Africa', intervention in conditions of por
Scriptura 105(2010), 519-531.

Mandela, N., 2010, Nelson Mandela, Conversations with myself, Macmillan, Londen.

Osmer, R.R., 2008, Practical Theology, An introduction, Eerdmans, Grand Rapids, MI/ Cambridge, V.K.

Pieterse, H.J.C., 1979, Skrifverstaan en prediking, NG Kerk-boekhandel, Pretoria. PMid: 432740

Pieterse, H.J.C. (ed.), 1995, Desmond Tutu's message, A qualitative analysis, Kok, Kampen.

Pieterse, H.J.C. (ed.), 2001, Desmond Tutu's Message, 2nd edn., Brill, Leiden.

Pieterse, H.J.C., 2002, 'Prediking in 'n postmoderne lewensgevoel', Praktiese Teologie in Suid-Afrika 17(1), 75-101.

Pieterse, H.J.C., 2005, 'Hoe kom God aan die woord in die prediking? 'n Vaste vertroue op God se beloftes is teologies noodsaaklik', Praktiese Teologie in Suid-Afrika 20(2), 110-128.

Pieterse, H.J.C., 2010, 'Die dialektiek tussen leser en teks: 'n Gesprek oor hermeneutiese homiletiek', Verbum et Ecclesia, 31(1), Art. \#391, 6 pages.

Polley, M.E., 1989, Amos and the Davidic Empire, Oxford University Press, New York/ Oxford. PMCid:1493900

Pope, S.J., 2007, Human evolution and Christian Ethics, Cambridge University Press, Cambridge. http://dx.doi.org/10.1017/CBO9780511550935

Smith, G.V., 1989, Amos, A commentary, Zondervan, Grand Rapids, MI.

Snyman, S.D., 1999, 'Amos', in W. Vosloo \& F.J. van Rensburg (reds.), Die Bybellenium Eenvolumekommentaar, bl. 1020-1034, Christelike Uitgewersmaatskappy (CUM), Vereeniging. 